Article

\title{
Anticancer Potential of L-Histidine-Capped Silver Nanoparticles against Human Cervical Cancer Cells (SiHA)
}

\author{
Rajmohamed Mohammed Asik ${ }^{1,+} \mathbb{\infty}$, Chidhambaram Manikkaraja ${ }^{1,+}\left(\mathbb{D}\right.$, Karuppusamy Tamil Surya ${ }^{1}$, \\ Natarajan Suganthy ${ }^{2}{ }^{-0}$, Archunan Priya Aarthy ${ }^{3}$, Domokos Mathe ${ }^{4,5,6}$, Muthusamy Sivakumar ${ }^{7} \mathbb{D}^{\circ}$, \\ Govindaraju Archunan $1,8, *$, Parasuraman Padmanabhan $9,10, * \mathbb{B}$ and Balazs Gulyas $9,10,11$
}

check for updates

Citation: Mohammed Asik, R.; Manikkaraja, C.; Tamil Surya, K.; Suganthy, N.; Priya Aarthy, A.; Mathe, D.; Sivakumar, M.; Archunan, G.;

Padmanabhan, P.; Gulyas, B.

Anticancer Potential of L-HistidineCapped Silver Nanoparticles against Human Cervical Cancer Cells (SiHA). Nanomaterials 2021, 11, 3154. https:// doi.org/10.3390/nano11113154

Academic Editor: Jose L. Arias

Received: 16 October 2021

Accepted: 12 November 2021

Published: 22 November 2021

Publisher's Note: MDPI stays neutral with regard to jurisdictional claims in published maps and institutional affiliations.

Copyright: (C) 2021 by the authors. Licensee MDPI, Basel, Switzerland. This article is an open access article distributed under the terms and conditions of the Creative Commons Attribution (CC BY) license (https:/ / creativecommons.org/licenses/by/ $4.0 /)$.
1 Department of Animal Science, Bharathidasan University, Tiruchirappalli 620024, India; mdasik91@gmail.com (R.M.A.); mraja.vishnu@gmail.com (C.M.); suriyakalyaniyadav@gmail.com (K.T.S.)

2 Department of Nanoscience and Technology, Alagappa University, Karaikudi 630003, India; suganthy.n@gmail.com

3 Department of Obstetrics and Gynecology, Rabindra Nath Tagore Medical College, Udaipur 313001, India; aarthyarchun94@gmail.com

4 Department of Biophysics and Radiation Biology, Semmelweis University, 1094 Budapest, Hungary; domokos.mathe@hcemm.eu

5 CROmed Translational Research Centers Ltd., 1094 Budapest, Hungary

6 In Vivo Imaging Advanced Core Facility, Hungarian Center of Excellence for Molecular Medicine (HCEMM), 1094 Budapest, Hungary

7 Ariviya Technologies Pvt Ltd., Pattukkottai, Thanjavur 614602, India; drsiva@ariviya.com

8 Dean-Research, Marudupandiyar College, Thanjavur 613403, India

9 Lee Kong Chian School of Medicine, Nanyang Technological University, Singapore 636921, Singapore; balazs.gulyas@ntu.edu.sg

10 Cognitive Neuroimaging Centre, Nanyang Technological University, 59 Nanyang Drive, Singapore 636921, Singapore

11 Department of Clinical Neuroscience, Karolinska Institute, 17176 Stockholm, Sweden

* Correspondence: archunan@bdu.ac.in (G.A.); ppadmanabhan@ntu.edu.sg (P.P.)

+ Authors contributed equally.

Abstract: This study reports the synthesis of silver nanoparticles using amino acid L-histidine as a reducing and capping agent as an eco-friendly approach. Fabricated L-histidine-capped silver nanoparticles (L-HAgNPs) were characterized by spectroscopic and microscopic studies. Spherical shaped L-HAgNPs were synthesized with a particle size of $47.43 \pm 19.83 \mathrm{~nm}$ and zeta potential of $-20.5 \pm 0.95 \mathrm{mV}$. Results of the anticancer potential of L-HAgNPs showed antiproliferative effect against $\mathrm{SiHa}$ cells in a dose-dependent manner with an $\mathrm{IC}_{50}$ value of $18.25 \pm 0.36 \mu \mathrm{g} / \mathrm{mL}$. Fluorescent microscopic analysis revealed L-HAgNPs induced reactive oxygen species (ROS) mediated mitochondrial dysfunction, leading to activation of apoptotic pathway and DNA damage eventually causing cell death. To conclude, L-HAgNPs can act as promising candidates for cervical cancer therapy.

Keywords: anticancer activity; L-histidine; silver nanoparticles; cervical cancer cells; apoptosis

\section{Introduction}

Nanotechnology is the engineering of functional systems at the molecular scale. In recent years, metal nanoparticles have become powerful materials in biomedicine [1-3]. Unique physicochemical properties of metal nanoparticles have increased the attention of researchers in recent decades in various fields such as catalysis and optoelectronics [4]. Among the metal nanoparticles, silver nanoparticles (AgNPs) have received much attention in the field of biomedicine due to their wide pharmacological properties such as antibacterial, antifungal, anti-inflammatory, antiviral activities, and biosensing properties [5-9]. Conventionally silver nanoparticles were synthesized through physical and chemical methods, which suffered certain limitations provoking the researchers toward biogenic sources 
for the synthesis of nanoparticles [10]. Multiple lines of evidence revealed the green synthesis of silver nanoparticles via plant, microbial, and algal sources [11]. Among the bioactive compounds from natural sources, amino acids have been used recently as biogenic sources, in which the amino, carboxyl, and side-chain groups act as perfect reducing and capping agents, playing vital roles in the morphology of synthesized nanoparticles. In addition, amino-acid-capped nanoparticles are biocompatible in nature, with good mechanical and thermal properties [12]. Natural amino acids such as glycine, tyrosine, and tryptophan have been used as reducing and surface functionalization agents for the fabrication of $\mathrm{Ag}$ nanoparticles coated thin films, which reported potent antibacterial and antibiofilm activities [13]. The amino acid L-histidine used in this study has an aliphatic amino group (pKa around 9.4) on the side chain and an imidazole group with a $\mathrm{pKa} \approx 6.04$, which becomes protonated at acidic $\mathrm{pH}$. Few studies have been reported on L-histidine-based nanoparticle synthesis for biomedical applications [14,15]. This study focused on an eco-friendly approach for the synthesis of L-histidine-capped silver nanoparticles (L-HAgNPs). Cervical cancer is the second-most prevalent cause of cancer-induced mortality in women mostly in developed countries (90\%), with a death rate of 3.5 million in 2012, which might increase to 5.5 million in 2030 if no effective therapy intervenes. Clinical and epidemiological survey reveals that people with human papilloma viral infection (HPV) have a high risk of cervical cancer. Treatment strategies available for cervical cancer include electrosurgical excision procedure, surgery, radiation, and chemotherapy, or a combination of chemo and radiation therapy, which posed severe side effects affecting the immune system, thereby enhancing the host susceptibility to disease, multidrug resistance, and toxicity [16]. Recent research revealed that nanoparticle-based therapy showed enhanced anticancer potential with reduced side effects. Multiple lines of evidence illustrated that noble metal nanoparticles synthesized through plant sources showed promising anticancer potential against cervical cancer in conjugation with chemotherapeutic drugs [17-19]. Despite the existence of several lines of evidence on the anticancer potential of Ag NPs, reports regarding histidine-capped Ag NPs are deficient, as L-HAgNPs were mostly used for electrochemical studies. Hence, this work focuses on the fabrication of AgNPs using L-histidine as a reducing agent and evaluates the anticancer potential against $\mathrm{SiHa}$ cells.

\section{Materials and Methods}

\subsection{Reagents Required}

Silver nitrate, Sodium hydroxide, Penicillin, streptomycin, trypsin, and EDTA were procured from Himedia laboratories (Mumbai, India), while L-histidine $\left(\mathrm{C}_{6} \mathrm{H}_{9} \mathrm{~N}_{3} \mathrm{O}_{2}\right)$ was obtained from Merck Specialties Pvt Ltd., Mumbai, India. SiHa cells were purchased from National Centre for Cell Science (NCCS), Pune, India. Cell culture medium was procured from Sigma Aldrich Pvt Ltd., Bangalore, India.

\subsection{Synthesis of L-HAgNPS}

L-histidine and silver nitrate were prepared in $3 \mathrm{mM}$ concentration in $30 \mathrm{~mL}$ of doubledistilled water (DD). $1 \mathrm{M} \mathrm{NaOH}$ was used as a stabilizing agent. L-histidine and $\mathrm{AgNO}_{3}$ were mixed in the ratio 5:1 in two necked glass stopper flasks and stirred for $10 \mathrm{~min}$, followed by the addition of $1 \mathrm{M} \mathrm{NaOH}$ until the $\mathrm{pH}$ reached 10 . The reaction mixture was stirred continuously at $65^{\circ} \mathrm{C}$ with a stirring speed of $450 \mathrm{rpm}$ for $4 \mathrm{~h}$ until the color changes to brown confirming the formation of Ag nanoparticles (AgNPs) [20].

\subsection{Characterization of Synthesized L-Histidine-Capped AgNPs (L-HAgNPs)}

Formation of L-HAgNPs was confirmed by the color transition from pale yellow to brown color, which was further substantiated by UV-Visible spectral analysis with a scan range of 200-800 nm (Jasco International Co., Ltd., Tokyo, Japan). Fourier-transform infrared spectroscopy (FTIR) of freeze-dried samples was conducted in a PerkinElmer FTIR spectrophotometer (PerkinElmer, MA, USA) with the wavenumber range $4000-400 \mathrm{~cm}^{-1}$ at a resolution of $1 \mathrm{~cm}^{-1}$. The particle size and surface charge were analyzed by dy- 
namic light scattering and zeta potential analyzer, while surface morphology and topology of the nanoparticles were characterized by AFM (Park System, Suwon, Korea), and scanning electron microscope (SEM) (Zeiss Supra-40 analytical SEM, Oberkochen Germany). The crystalline nature of synthesized Nanoparticles was assessed by X-ray Powder Diffraction (XRD) analysis (Rigaku Minifex-II, Tokyo, Japan) with $\mathrm{Cu}-\mathrm{K} \alpha$ radiation of wavelength $1.54 \AA$.

\subsection{In Vitro Cytotoxicity of L-HAgNPS}

SiHa cells were maintained in DMEM medium supplemented with fetal bovine serum $(10 \%)$ and antibiotics $(2 \%)$ at $37{ }^{\circ} \mathrm{C}$ in a $\mathrm{CO}_{2}$ incubator $(5 \%)$ with $95 \%$ humidity. The passage number of cells used for experimentation was below 15 . Briefly, $5 \times 10^{3}$ cells per well were seeded in 96 well microtiter plate and exposed to different doses of L-HAgNPs (20-100 $\mu \mathrm{g} / \mathrm{mL})$ with DMSO as negative control and cisplatin as a positive control for $24 \mathrm{~h}$, followed by incubation with 3-(4,5-Dimethylthiazol-2-yl (MTT) (5 mg/mL) for $3 \mathrm{~h}$ at a physiological temperature under dark condition [21]. Formed purple-colored crystals were dissolved in Dimethyl sulfoxide (DMSO) and the color intensity was measured at $570 \mathrm{~nm}$ using an ELISA plate reader (Bio-Rad, iMark, Hercules, CA, USA), and the percentage of cytotoxicity was calculated. IC 50 was calculated using probit software analysis.

\subsection{Effect of L-HAgNPS on Intracellular ROS Level}

Intracellular reactive oxygen species (ROS) levels in L-HAgNPs treated cells were assessed by using nonspecific esterase dichlorofluorescein diacetate, which, on oxidation with cellular peroxides, form green fluorescing compound 2,7-dichlorofluorescein. Cells after exposure to L-HAgNPs and cisplatin at its $\mathrm{IC}_{50}$ concentration were incubated with $\mathrm{H} 2 \mathrm{DCFDA}$ at $37^{\circ} \mathrm{C}$ for $30 \mathrm{~min}$. Fluorescence intensity was measured by using a microplate reader with $\lambda \mathrm{Ex} / \lambda \mathrm{Em}$ of $485 \mathrm{~nm} / 535 \mathrm{~nm}$ [22], and the cells were also visualized under a fluorescent microscope.

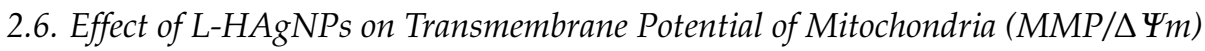

Alteration in the transmembrane potential of mitochondria was assessed using fluorescent dye JC-1, which emits orange-red fluorescence in the healthy cells and green fluorescence on membrane depolarisation. SiHa cells cultured on coverslips were exposed to cisplatin and L-HAgNPs for $12 \mathrm{~h}$, followed by JC-1 staining $(10 \mu \mathrm{M} / \mathrm{mL})$ for $30 \mathrm{~min}$ in dark $37^{\circ} \mathrm{C}$. Excess dye was removed by PBS wash and the cells were viewed under a fluorescent microscope at absorption/emission maxima of 485/585 nm to observe the alteration in MMP.

\subsection{Assessment of Apoptotic Effect of L-HAgNPs in SiHa Cells}

\subsubsection{Acridine Orange (AO) and Ethidium Bromide (EB) Dual Staining}

Morphological changes in the cells due to apoptosis were evaluated based on the methodology of Spector et al. (1998) [23]. SiHa cells seeded $\left(0.3 \times 10^{6}\right.$ cells /well) in a six-well plate were exposed to L-HAgNPs and cisplatin at its $\mathrm{IC}_{50}$ concentration for $24 \mathrm{~h}$, followed by ice-cold PBS ( $\mathrm{pH}$ 7.4) wash. Cells were then treated with an equal proportion of $\mathrm{AO} / \mathrm{EtBr}(1 \mathrm{mg} / \mathrm{mL})$ for $10 \mathrm{~min}$, and excess dye was removed and visualized under a fluorescent microscope (Carl Zeiss, Axioscope 2 plus) with blue and green filter. In each sample, the percentage of apoptotic and necrotic cells were quantified by examination of around 300 cells for normal, apoptotic, and necrotic morphology.

\subsubsection{Hoechst 33528 Staining}

Overnight seeded cells exposed to L-HAgNPs were harvested and stained with Hoechst 33,258 dye (1 mg/mL) [24]. The cells with normal and abnormal nuclei were visualized under a fluorescent microscope using a blue filter (377-355 nm). Over 300 cells were counted, and the percentage of cells with normal and abnormal nuclei was calculated. 


\subsubsection{Comet Assay}

To assess the DNA damage induced by L-HAgNPs, a comet assay was performed based on the methodology of Tice et al. (2000) [25], with slight modifications. Cells exposed to L-HAgNPs were harvested, mixed with $1 \%$ low melting agarose, and coated on slides, followed by layering of normal melting agarose. Slides were incubated lysis buffer (TBE, $\mathrm{pH}$ 8.4, containing 2.5\% Sodium dodecyl sulfate (SDS)) for $10 \mathrm{~min}$ and then subjected to electrophoresis in TBE buffer for $10 \mathrm{~min}$ without SDS at $2 \mathrm{~V} / \mathrm{cm}$ and $80 \mathrm{~mA}$, respectively. Slides were subjected to EtBr staining, washed, covered with coverslips, and stored at $4{ }^{\circ} \mathrm{C}$ until visualized under a fluorescent microscope with excitation/emission wavelength of 515/560 nm. Tail length, olive tail moments were measured using Komet 5.5 image analysis software (Komet image analysis version 5.5, Oxford instruments, Abingdon, UK).

\subsubsection{Annexin V-Cy3 Staining}

Annexin V-Cy3 dual staining was carried out to differentiate the live (fluoresces green), necrotic (fluoresces red), and apoptotic cells (exhibits both red and green fluorescence) A549 cells $\left(0.3 \times 10^{6}\right.$ cells / well) grown in coverslip were exposed to L-HAgNPs and Cislatin at its $\mathrm{IC}_{50}$ concentration for $12 \mathrm{~h}$, followed by a wash with PBS and annexin binding buffer (1X). Cells were stained with dual staining solution (annexin V-cy3 and 6-CFDA) for $10 \mathrm{~min}$ in dark and visualized under a fluorescent microscope. Around 300 cells from each group were counted, and the percentage of viable and dead (apoptotic and necrotic) cells were calculated.

\subsection{Statistics Analysis}

Results obtained from three independent experiments were represented as Mean $\pm \mathrm{SD}$ and analyzed using one-way analysis of variance (ANOVA), and the average value was compared by Duncan's multiple comparison tests (SPSS 17.0).

\section{Results}

\subsection{Formation of $A g N P s$}

Reduction of $\mathrm{Ag}\left(\mathrm{NO}_{3}\right)_{2}$ by L-histidine was identified by the color transition from colorless to brown color, which was further confirmed by UV-Visible spectral analysis (Figure 1I). A sharp absorption peak was observed between 400 and $420 \mathrm{~nm}$. The absorption peak of AgNPs synthesized using various molar ratios of $\mathrm{AgNO}_{3}$ with L-histidine (1:1, $1: 2$, and 1:2.5) showed peaks at 400,415, and $420 \mathrm{~nm}$, respectively (Figure 1II). Figure 1III showed the absorption spectrum of Ag NPs at various time intervals during its synthesis illustrating the time-dependent reduction of $\mathrm{AgNO}_{3}$ to $\mathrm{AgNPs}$ with maximum reduction at $50 \mathrm{~min}$.

\subsection{Particle Size Analysis by DLS}

The size of synthesized AgNPs was determined using particles size distribution analysis by measuring the random changes in the DLS. It was found that the average size of L-HAgNPs was observed to be $445.3 \pm 36.44,145.5 \pm 47.99$, and $47.43 \pm 19.83 \mathrm{~nm}$, respectively for the precursor $\mathrm{AgNO}_{3}$ with L-histidine in the ratio 1:1, 1:2, and 1:2.5 (Figure 2I $(\mathrm{A}-\mathrm{C})$ ). The higher the ratio of $\mathrm{AgNO}_{3}$ with L-histidine (1:2.5) used for the fabrication of AgNPs, the lower the particle size. The polydispersity index was found to be $0.5 \pm 0.2$, which shows a monodisperse distribution for the particles. The zeta potential value of L-HAgNPs synthesized using a precursor ratio of 1:2.5 was observed to be $-20.5 \pm 0.95 \mathrm{mV}$ (Figure 2II).

\subsection{X-ray Diffraction Studies of Silver Nanoparticles}

The nature and crystalline structure of L-HAgNPs were assessed by X-ray diffraction analysis, and results are depicted in Figure 3I. XRD analysis of L-HAgNPs showed diffraction peaks at $38.1^{\circ}, 44.3^{\circ}, 64.7^{\circ}, 77.1^{\circ}$ assigned to the planes (111), (200), (220), (311) facet, corresponding to JCPDS No:01-087-0597, thereby confirming face-centered cubic 
crystalline structure (Figure 3I). The mean crystal size of L-HAgNPs was calculated using Debye-Scherrer's formulae as $9.76 \mathrm{~nm}$.

(I)

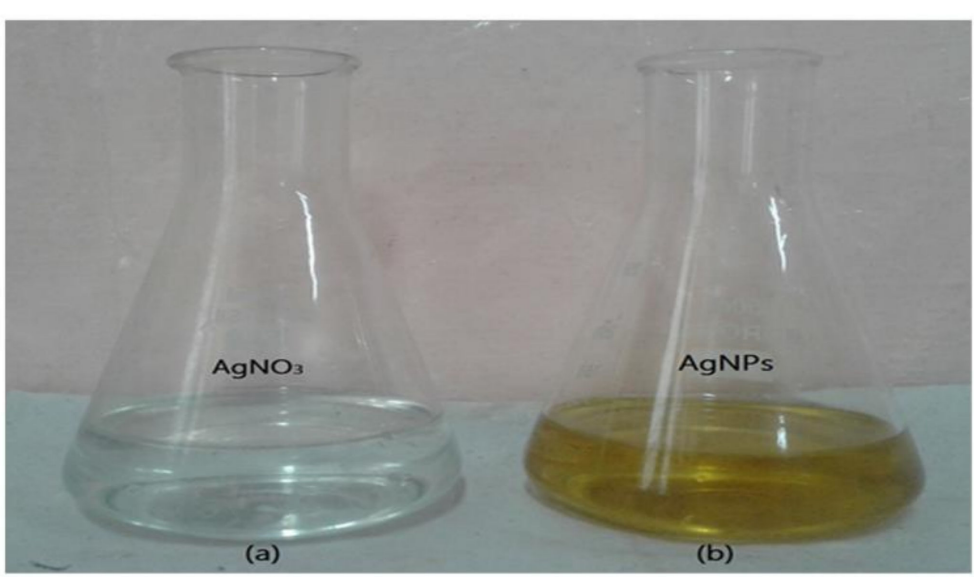

(II)

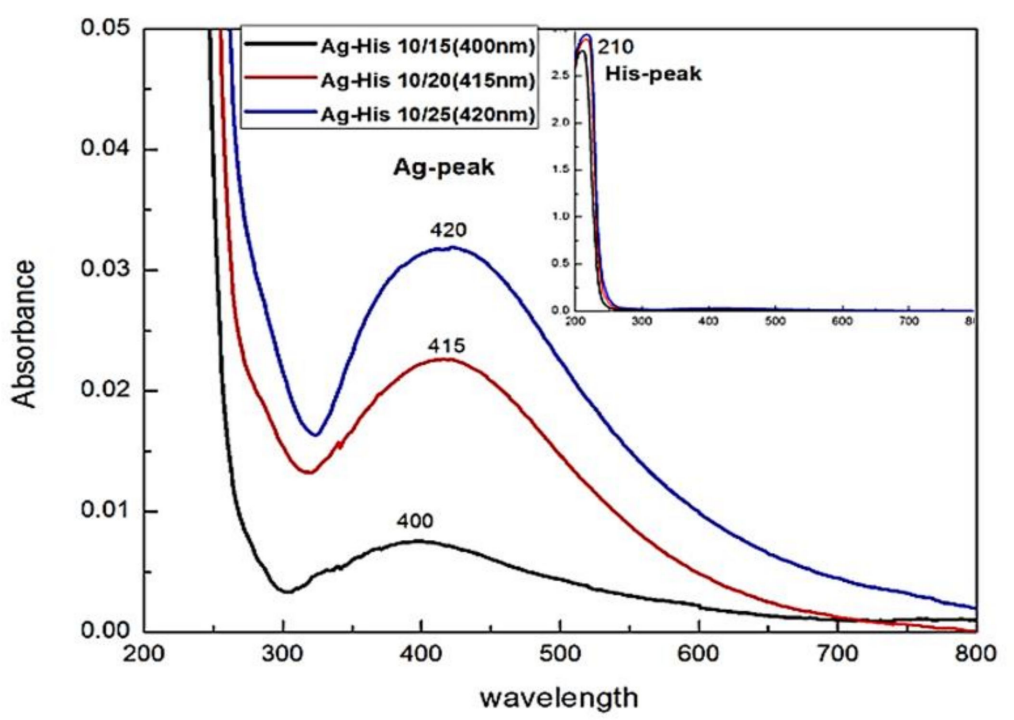

(III)

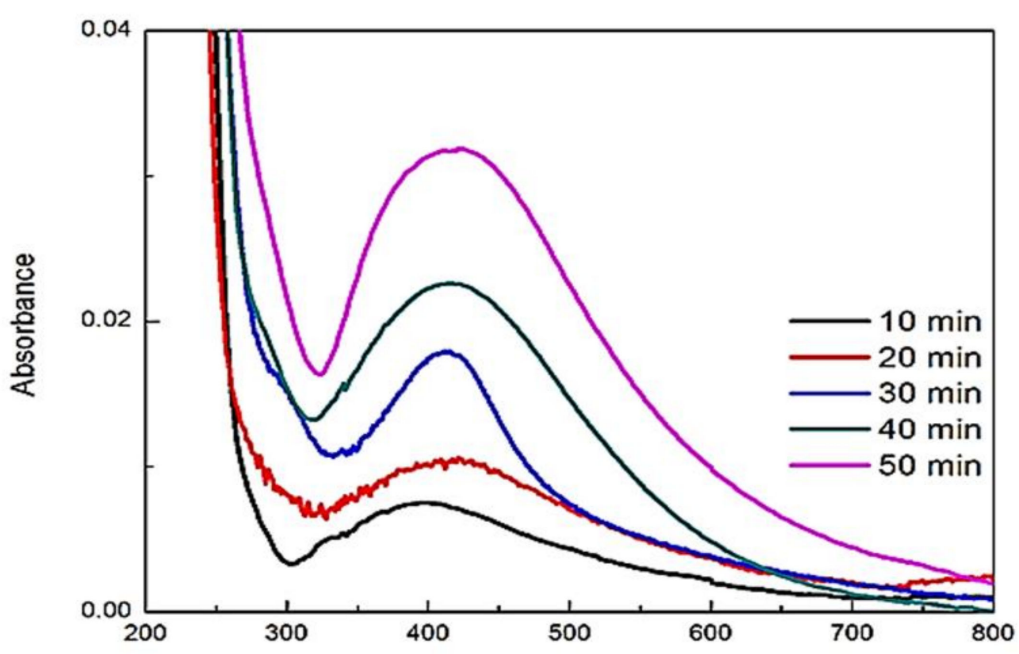

Figure 1. (I) Color transition illustrating the formation of AgNPs; (II) UV-Visible spectra of AgNPs synthesized using various molar ratios of $\mathrm{AgNO}_{3}$ and L-histidine; (III) UV-Visible spectrum illustrating the optimization of time for the synthesis of AgNPs. 
(I) (A)

(B)
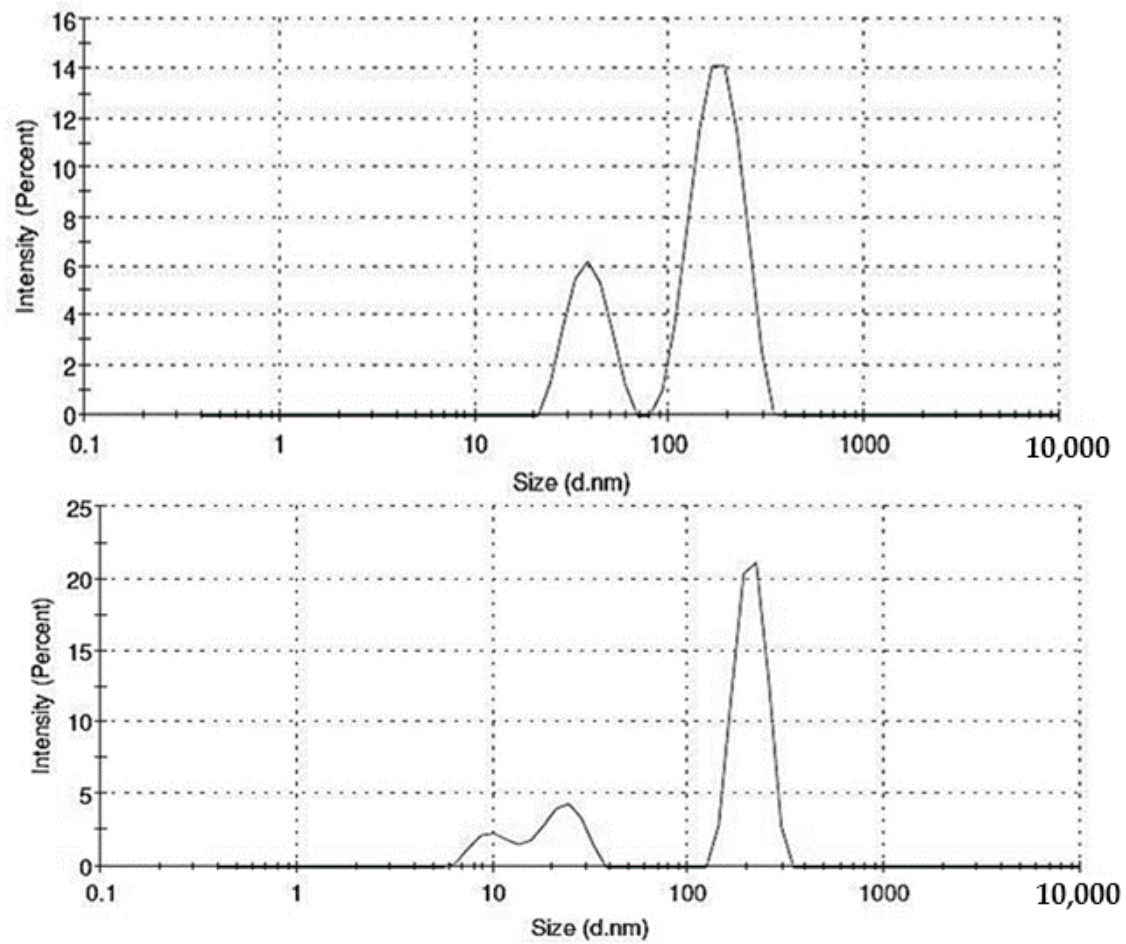

(C)

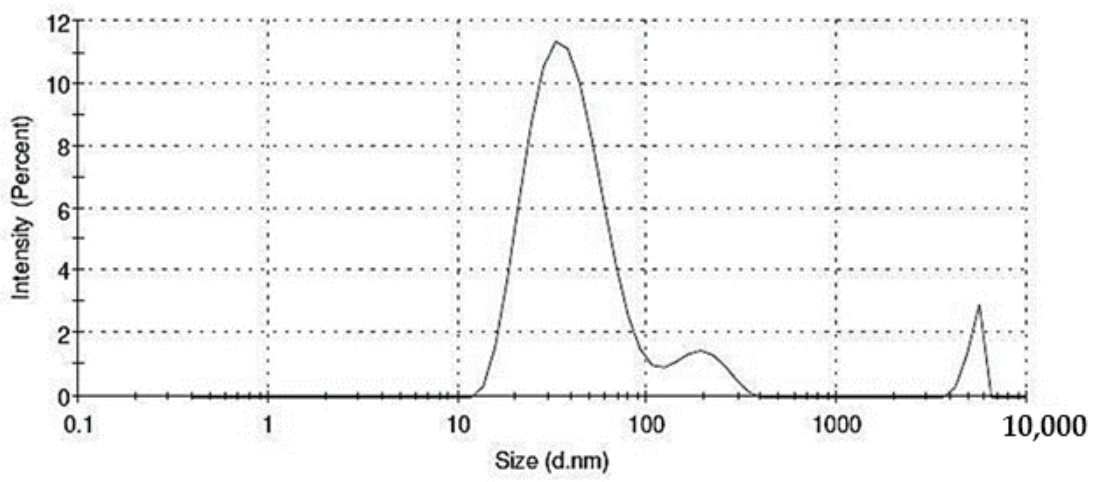

(II)

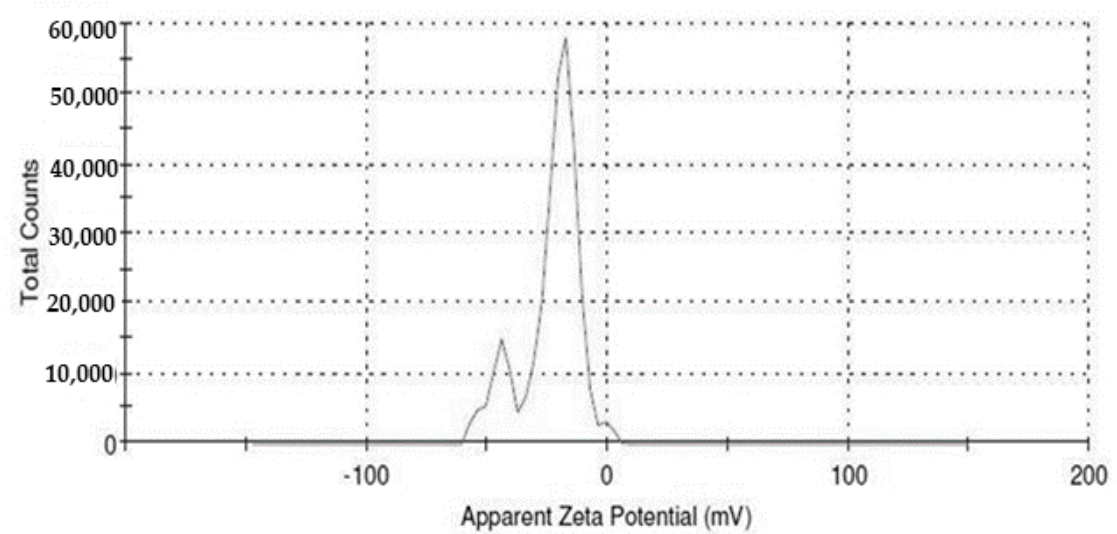

Figure 2. (I) DLS spectrum illustrating the particle size of AgNPs synthesized using various molar ratios of precursor and (A) $\mathrm{AgNO}_{3}$ : L-histidine 1:1, (B) $\mathrm{AgNO}_{3}$ : L-histidine 1:2, and (C) $\mathrm{AgNO}_{3}$ : L-histidine 1:2.5; (II) zeta potential analysis of AgNPs. 
(I)
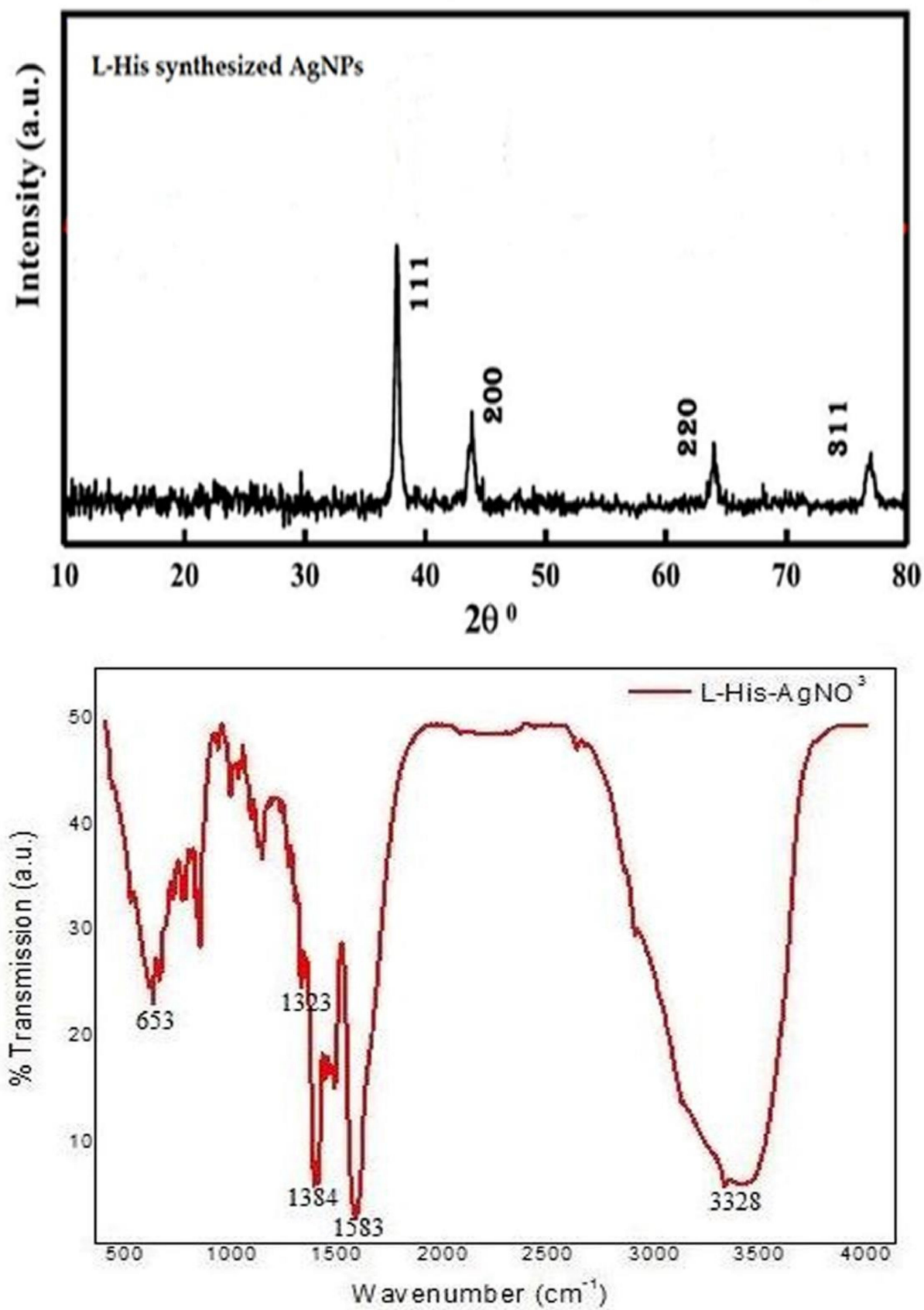

Figure 3. (I) X-ray diffraction pattern of L-HAgNPs; (II) Fourier-transform infrared spectra of L-HAgNPs.

\subsection{Functional Group Analysis}

The functional group involved in the chemical interaction between L-histidine and AgNPs was evaluated using FT-IR and illustrated in Figure 3II. Visible bands were observed at $653 \mathrm{~cm}^{-1}, 1323 \mathrm{~cm}^{-1}, 1384 \mathrm{~cm}^{-1}, 1583 \mathrm{~cm}^{-1}$, and $3328 \mathrm{~cm}^{-1}$, which were assigned to $\mathrm{C}-\mathrm{H}$ group bending vibration, $\mathrm{C}-\mathrm{N}$ stretching vibration of imidazole group and $-\mathrm{COOH}$ group, $\mathrm{N}-\mathrm{H}$ bending, $\mathrm{O}-\mathrm{H}$ group of $\mathrm{H}_{2} \mathrm{O}$ depicting the presence of histidine in L-HAgNPs. The characteristic peak at $1563 \mathrm{~cm}^{-1}$ and $1460 \mathrm{~cm}^{-1}$ depicts the stretching frequencies of carboxylate $\left(\mathrm{COO}^{-}\right)$, and the peak at $3328 \mathrm{~cm}-1$ corresponds to the stretching vibration of the $\mathrm{N}-\mathrm{H}$ group, which is analogous to aminocarboxylates and carboxylates present in L-histidine (Figure 3II). 


\subsection{Size and Morphology Analysis of L-HAgNPs by SEM, HR-TEM, and AFM}

The size, shape, and surface morphology of synthesized nanoparticles were analyzed through SEM, and results are illustrated in Figure 4I(A-C). Results showed the presence of needle-shaped crystalline structure in L-HAgNPs in different magnification. The 2D and 3D images of AFM results revealed the presence of irregular spherical shaped nanoparticles, and the average height of L-HAgNPs was observed to be between scale 10 to $16 \mathrm{~nm}$ (Figure 4II(A,B)). L-histidine acts as a capping agent for AgNPs, thereby preventing the agglomeration of AgNPs. Further, the morphology of AgNPs was assessed by HR-TEM, and the results depicted the presence of dark-colored uniform-sized AgNPs capped by light-colored L-His material with an average size of $20 \mathrm{~nm}$ (Figure 4II(C,D)).
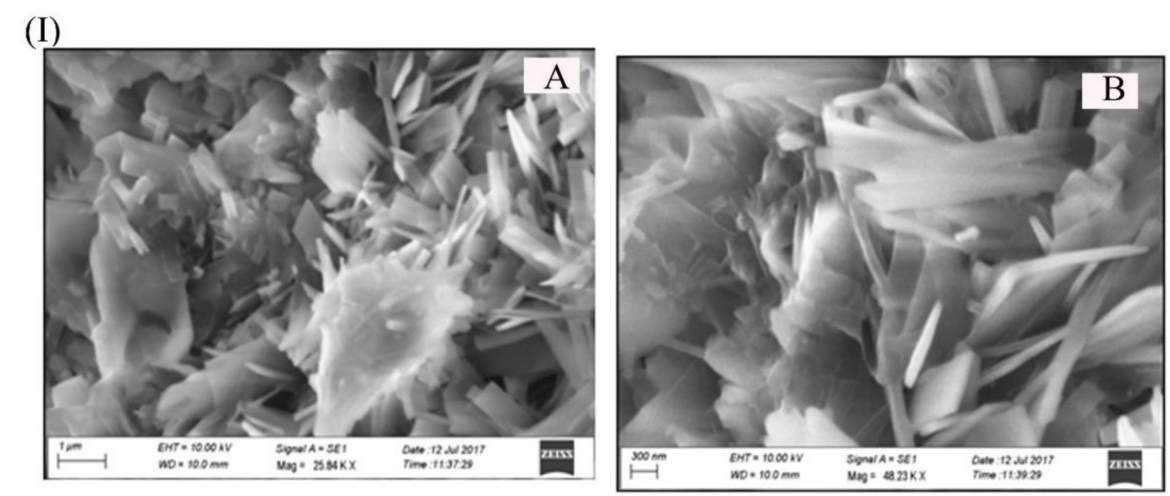

(II)
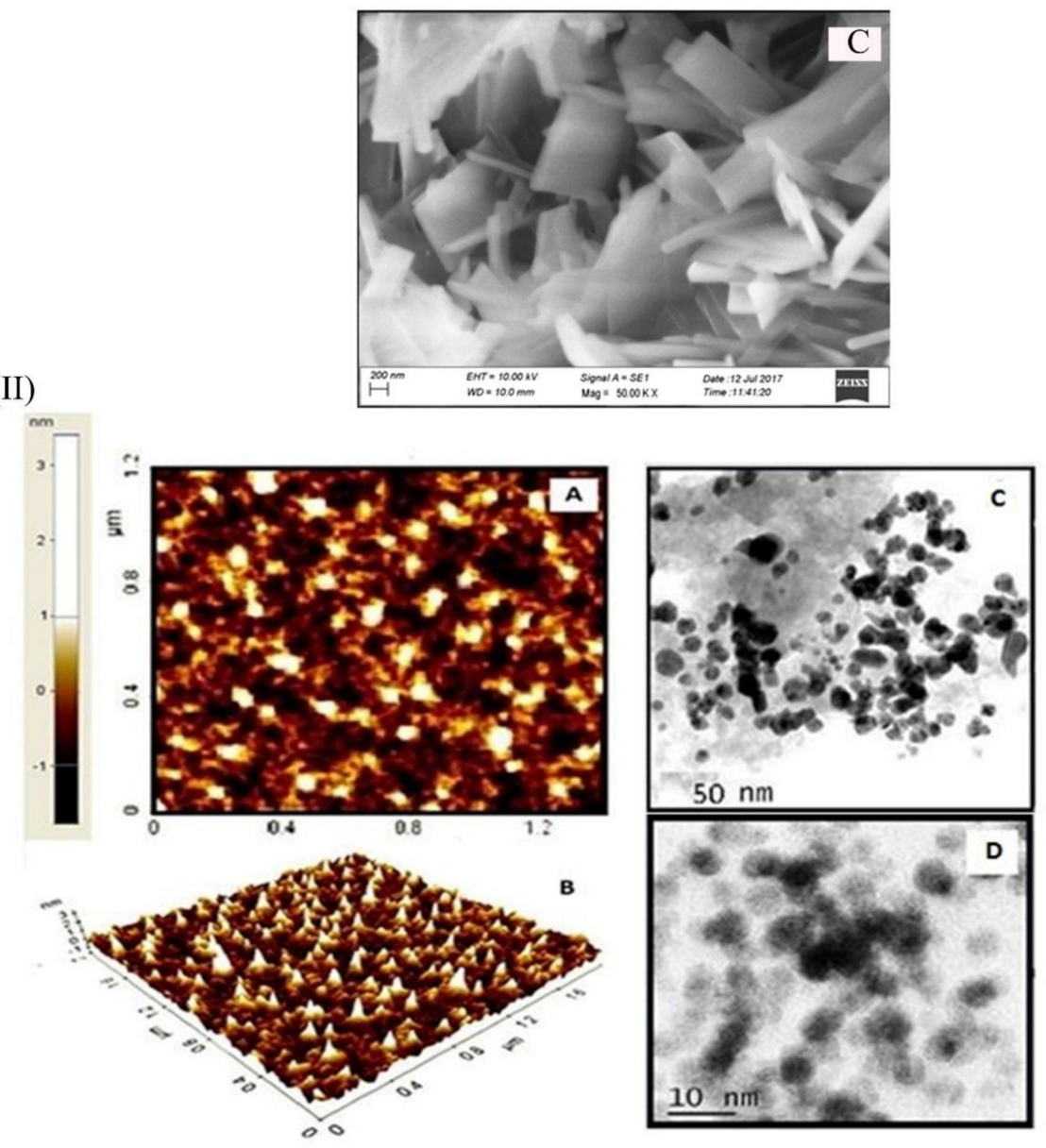

Figure 4. Morphological assessment of L-HAgNPs by (I) SEM images at different magnifications: (A) $1 \mu \mathrm{M}$, (B) $300 \mathrm{~nm}$, and (C) $200 \mathrm{~nm}$; (II) AFM micrograph: (A) 2D image, (B) 3D image, and (C,D) TEM micrographs. 


\subsection{Anticancer Potential of L-HAgNPs against SiHa Cells}

3.6.1. Dose-Dependent Cytotoxicity Effect of L-HAgNPs in SiHa Cells

Antiproliferative effect of L-HAgNPs against $\mathrm{SiHa}$ cells was assessed using MTT assay; L-HAgNPs showed a dose-dependent cytotoxic effect $(20-100 \mu \mathrm{g} / \mathrm{mL})$, with $\mathrm{IC}_{50}$ value of $18.25 \pm 0.36 \mu \mathrm{g} / \mathrm{mL}$, similar to positive control cisplatin, whose $\mathrm{IC}_{50}$ value was observed to be $19.15 \pm 0.16 \mu \mathrm{g} / \mathrm{mL}$ (Figure $5 \mathrm{I}$ ). Phase-contrast microscopic analysis revealed the presence of intact cells with normal cervical epithelial morphology in vehicle control cells, while L-HAgNPs and cisplatin-treated cells showed reduced colonies with shrunken morphology, disrupted cell membrane, and fragmented nuclei (Figure 5II).

(I)

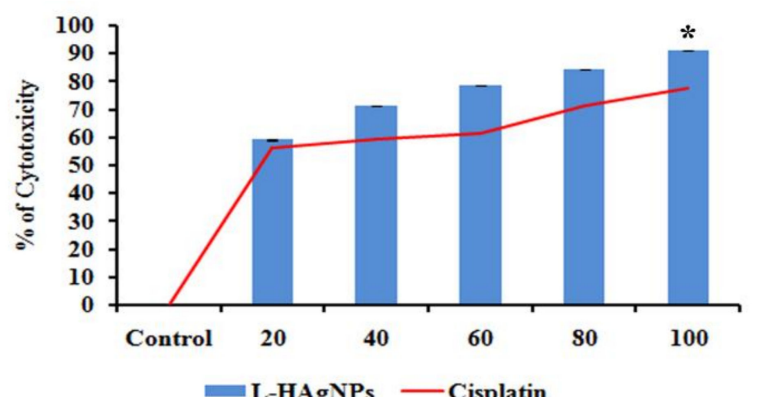

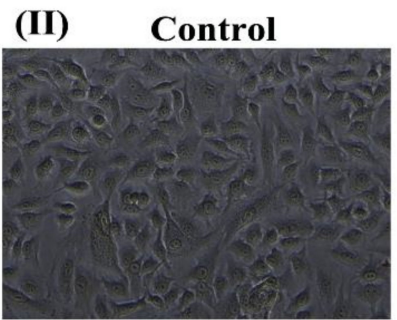

(III) Control

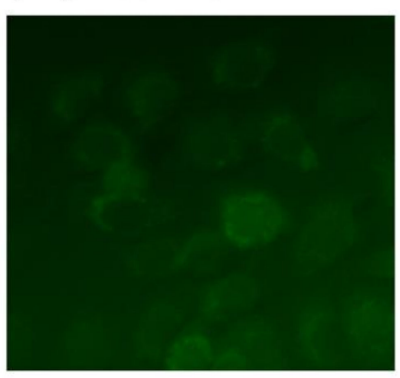

(IV)

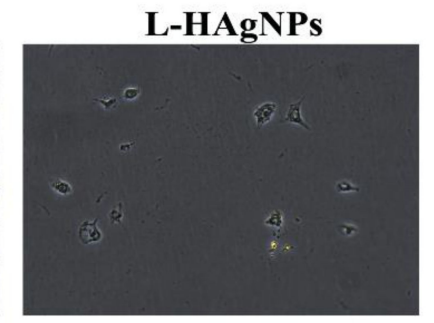

L-HAgNPs
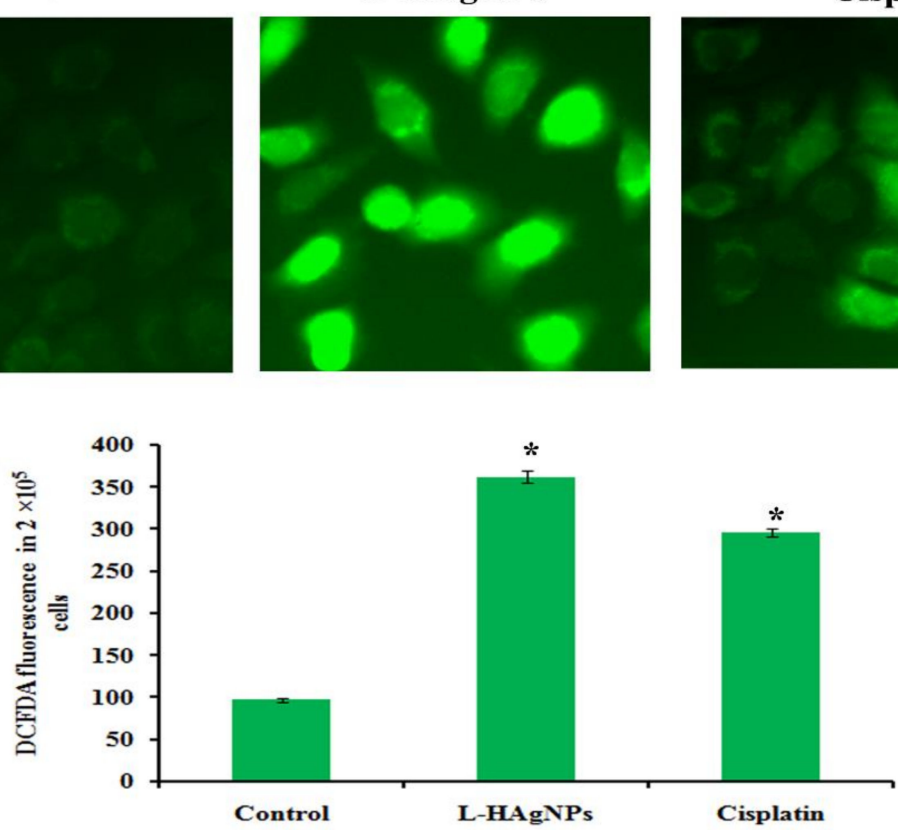

Cisplatin

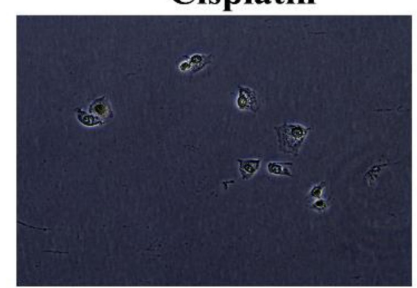

Cisplatin

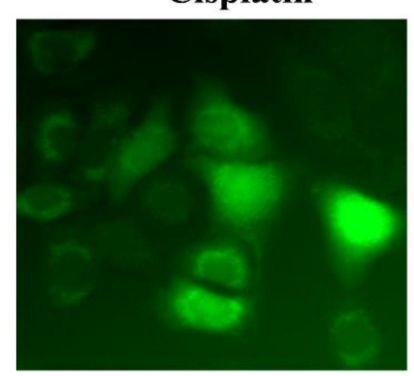

Cisplatin

Figure 5. (I) Antiproliferative effect of L-HAgNPs against SiHa cells; (II) phase-contrast microscopic images to assess structural changes in cells treated with L-HAgNPs; (III) fluorescent images illustrating intracellular ROS level; (IV) bar graph depicting quantitative measurement of green fluorescent intensity proportional to ROS level. ${ }^{*} p<0.05$ denotes statistical significance between control vs. treated groups. 


\subsubsection{Effect of L-HAgNPs on the Intracellular ROS Level of Treated SiHa Cells}

To elucidate the mechanism behind apoptosis in L-HAgNPs treated SiHa cells, endogenous ROS level was measured, and the results are illustrated in Figure 5III,IV. Fluorescent microscopic studies revealed the presence of intense green fluorescent cells in L-HAgNPs treated and cisplatin-treated groups, while control cells showed less intense fluorescence. Quantitative analysis revealed fourfold enhanced fluorescent intensity (408.33 \pm 6.83 a.u.) in L-HAgNPs when compared with control cells, while cisplatin-treated cells showed threefold increase in fluorescent intensity $(296.33 \pm 4.926$ a.u $)$, depicting the fact that L-HAgNPs enhanced the intracellular ROS level the key mediator of apoptosis.

\subsubsection{Effect of L-HAgNPs on the Transmembrane Potential of Treated SiHa Cells}

To assess the impact of L-HAgNPs on mitochondrial function in SiHa cells, its transmembrane potential was assessed using fluorescent dye JC-1. Figure 6I revealed the presence of red fluorescence in vehicle control cells, while in L-HAgNPs and cisplatin-treated cells showed disappearance of red fluorescence and appearance of green fluorescence. Quantification of red-to-green fluorescent ratio revealed that L-HAgNPs and cisplatin-treated cells showed a sixfold reduction when compared with vehicle control (Figure 6II).

\subsubsection{Assessment of DNA Damage Induced in L-HAgNPs by Comet Assay}

To evaluate the impact of L-HAgNPs on DNA, single-cell gel electrophoresis was carried out, and the results are shown in Figure 6III,IV. Vehicle control groups revealed cells with intact nuclei, which appear round (Class 0), while L-HAgNPs and cisplatin-treated groups showed the presence of nuclei with fragmented DNA, which migrates faster as tail, giving the appearance of comet (Classes 2 and 3) (Figure 6III). Quantification of tail moment and percentage of DNA in the tail showed a threefold increase in tail moment $(1.56 \pm 0.013)$, olive tail moment $(1.721 \pm 0.001)$, and $\%$ of DNA in tail $(97.0 \pm 0.08)$ in L-HAgNP-treated groups when compared with vehicle control.

\subsubsection{Effect of L-HAgNPs on Apoptosis by AO/EtBr Dual Staining}

To determine the extent of apoptosis induced by L-HAgNPs in SiHa cells, $\mathrm{AO} / \mathrm{EtBr}$ double staining was carried out. Figure 7I showed the presence of intact green fluorescent cells with organized structure in vehicle control, while L-HAgNP- and cisplatin-treated groups illustrated the presence of both granular yellow/green stained cells and orange red fluorescence cells. Quantification of normal, apoptotic and necrotic cells showed $90 \pm 1 \%$ viable intact cells, $7.33 \pm 1.52 \%$ apoptotic cells, and $2.667 \pm 0.57 \%$ necrotic cells in vehicle control. L-HAgNPs treated groups exhibited $24 \pm 3.06 \%$ viable cells, $70 \pm 5 \%$ apoptotic cells, and $6 \pm 1.73 \%$ necrosis. Similar results were observed in cisplatin treated cells ( $34 \pm 6.33 \%$ viable cells: $58 \pm 2.64 \%$ apoptosis and $6.33 \pm 2.30 \%$ necrosis) (Figure 7II).

\subsubsection{Assessment of Nuclear Damage by Hoechst 33528 Nuclear Staining}

To assess whether apoptosis is due to nuclear damage Hoechst 33,528 staining was carried out, and the results are illustrated in Figure 7III,IV. Control cells showed presence of cells with intact nucleus and cytoplasm exhibiting light blue fluorescence, while L-HAgNPtreated cells revealed the presence of intense blue-fluorescent cells, indicating the presence of apoptotic nuclei (Figure 7III). Percentage of apoptotic and necrotic cells were assessed, and the results indicated that L-HAgNP-treated cells showed $31 \pm 3.6 \%$ normal nuclei and $69 \pm 3.6 \%$ apoptotic nuclei when compared with vehicle control $(80 \pm 5 \%$ normal nuclei and $20 \pm 5 \%$ abnormal nuclei). Cisplatin-treated cells showed $40 \pm 5 \%$ cells, with intact nuclei and $60 \pm 5.2 \%$ damaged nuclei (Figure 7IV).

\subsubsection{Assessment of Apoptotic Effect of L-HAgNPs by Annexin V-Cy3 Dual Staining}

To substantiate the apoptosis mediated cell death in L-HAgNP-treated groups annexin V-Cy3 dual staining was performed, and the results are shown in Figure 8. Results revealed the presence of green-fluorescent cells stained with annexinV-Cy3, while cells 
treated with L-HAgNPs and cisplatin exhibited both red and green fluorescence, indicating apoptosis mediated cell death (Figure 8I). Quantification of cells showed that L-HAgNPtreated groups exhibited $55.66 \pm 2.08 \%$ apoptotic cells, $5.33 \pm 1.52 \%$ necrotic cells and $39 \pm 3.6 \%$ normal cells when compared with control, which showed $84.66 \pm 4 \%$ healthy cells. Cisplatin-treated groups showed $54.33 \pm 4.04 \%$ healthy cells, $36.66 \pm 4.16 \%$ apoptotic cells and $9 \pm 1.73 \%$ necrotic cells (Figure $8 \mathrm{II}$ ).

(I)

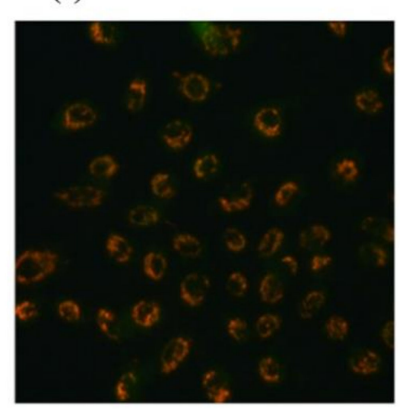

(II)

(III)
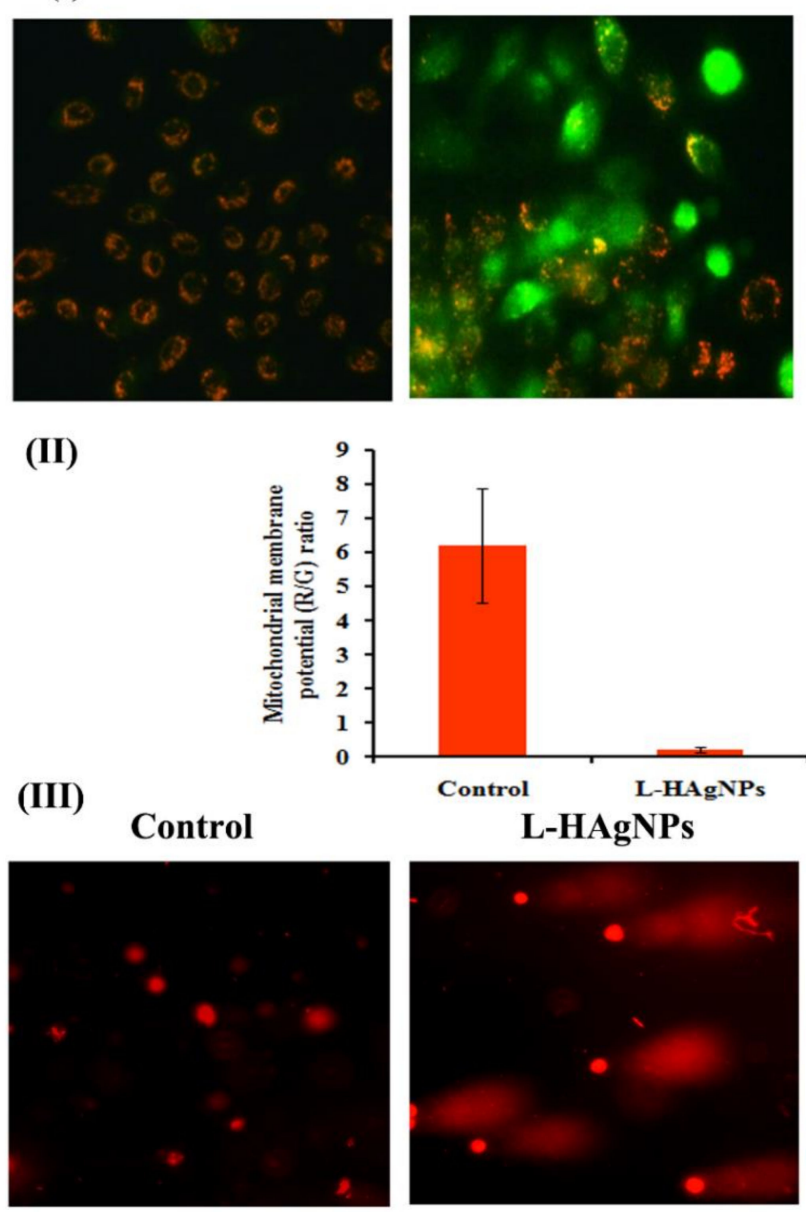

\section{Cisplatin}

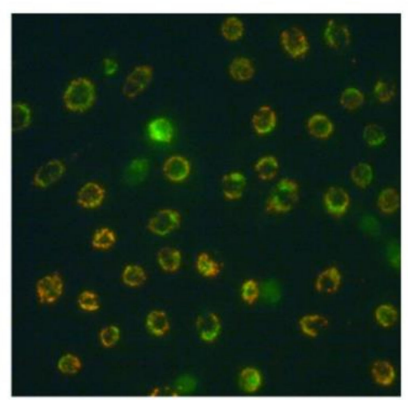

(IV)

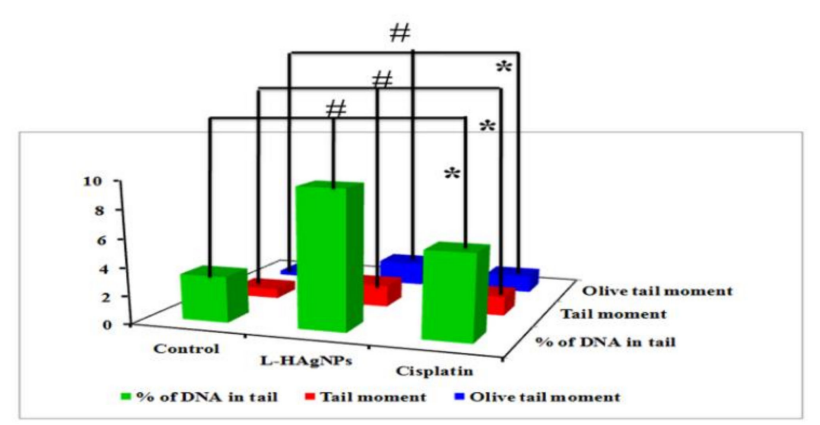

Figure 6. (I) Fluorescent micrograph revealing transmembrane potential of cells treated with LHAg NPs; (II) bar graph representing quantification of MMP; (III) fluorescent microscopic images revealing DNA damage induced by L-HAgNPs; (IV) quantitative measurement of degree of DNA damage. Data are expressed as mean \pm SD of triplicate assays. Images were captured at $20 \times$ magnification, respectively. \# and ${ }^{*} p<0.0001$ denotes statistical significance between control vs. L-HAgNPs treated groups and control vs. cisplatin-treated groups. 
(I)

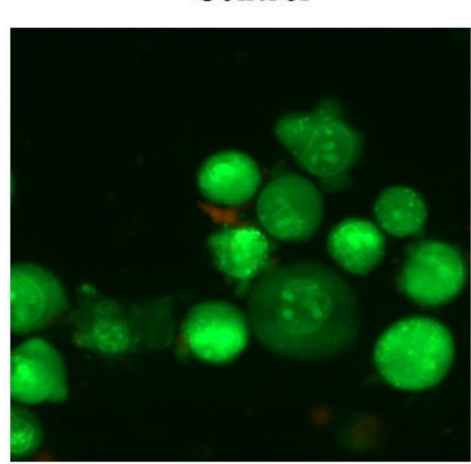

(II)

(III)
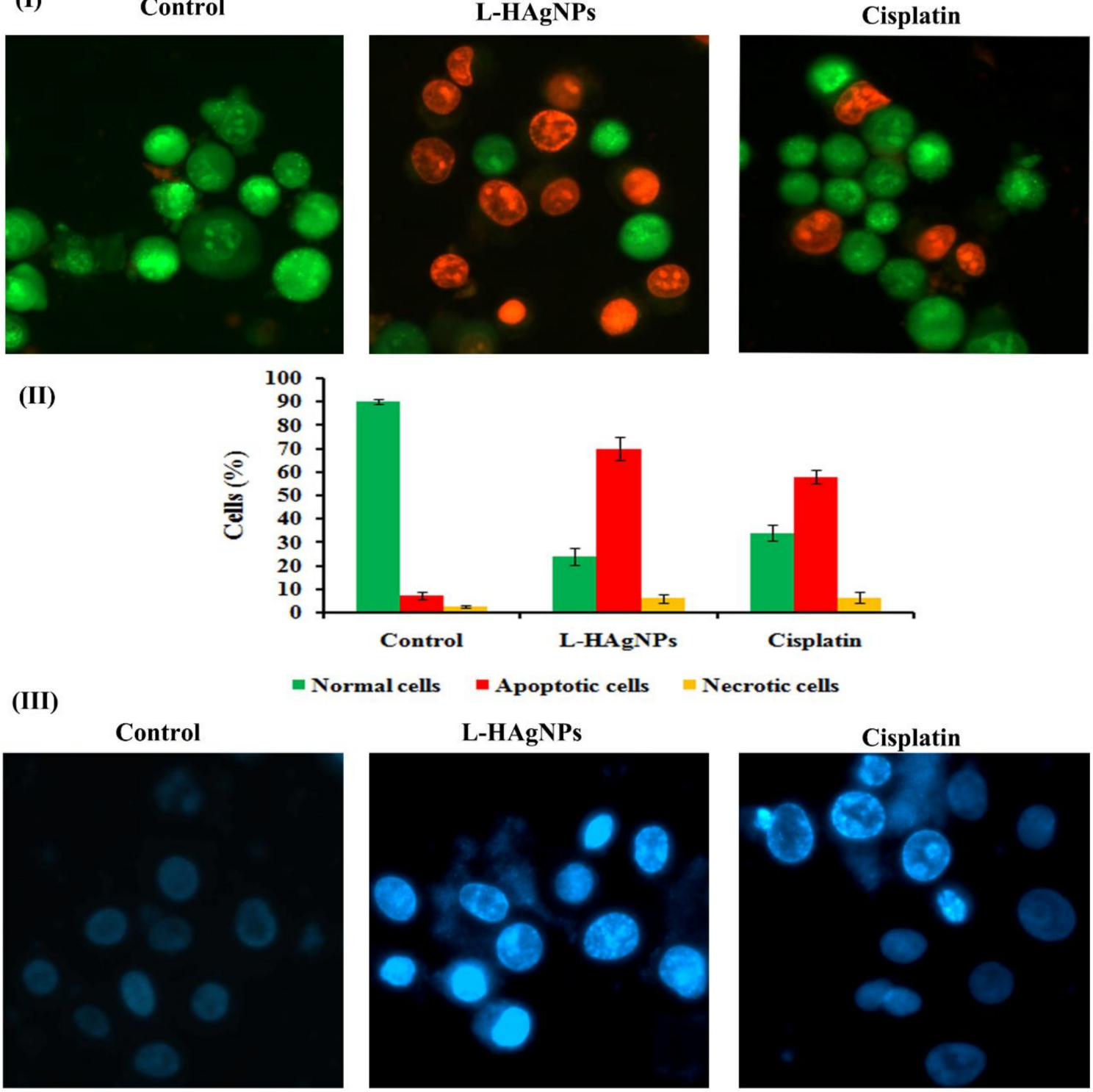

al cells

apoptotic cells $=$ Necrotic cells
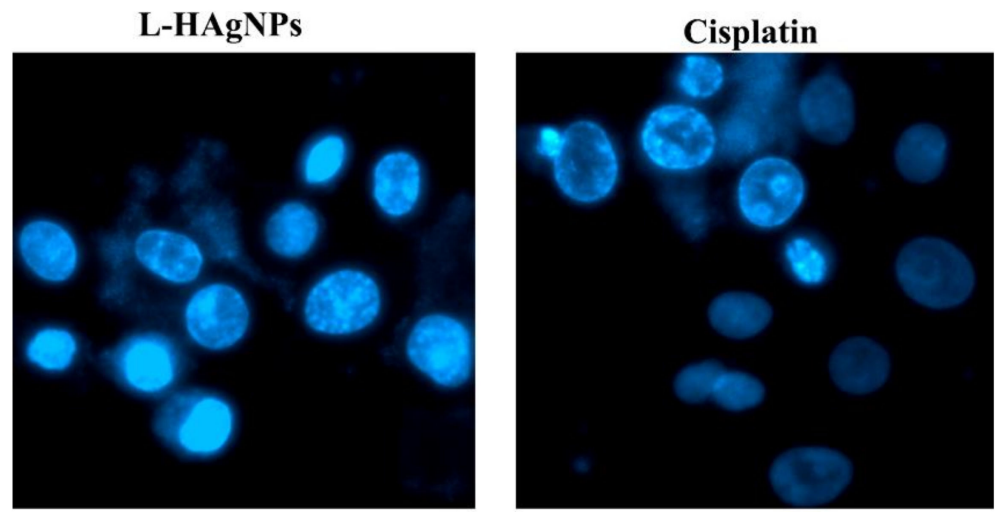

(IV)

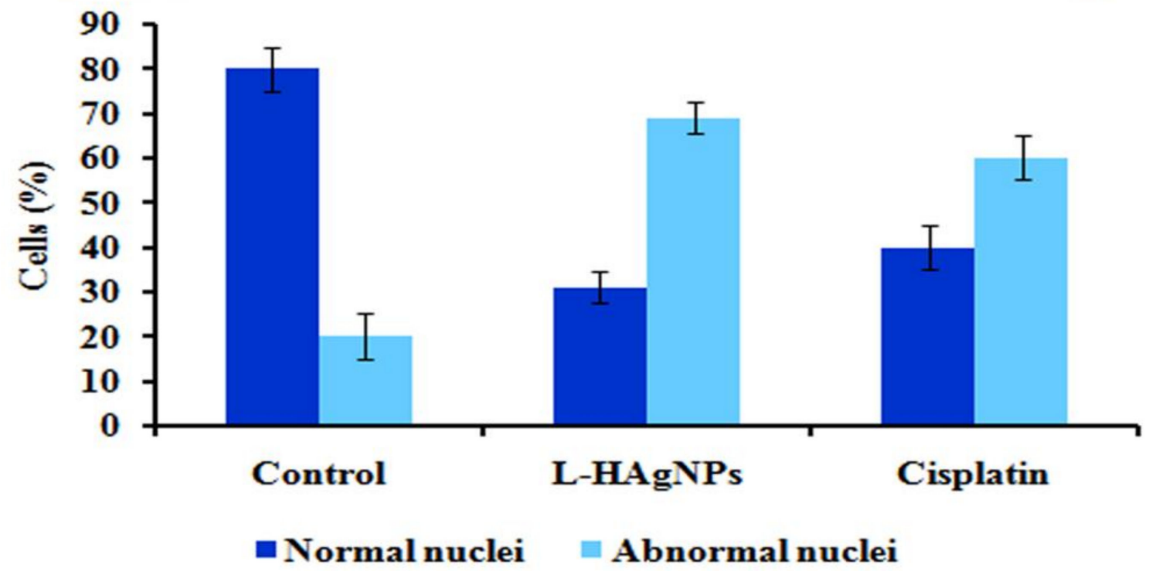

Figure 7. Assessment of apoptotic effect of L-HAgNPs against cervical cancer cells: (I) fluorescent image of AO/EtBr dual staining; (II) quantification of apoptotic and necrotic cells; (III) images representing nuclear damage by Hoechst 33,528 staining; (IV) bar graph illustration percentage of cells with normal and apoptotic nuclei. 
(I)
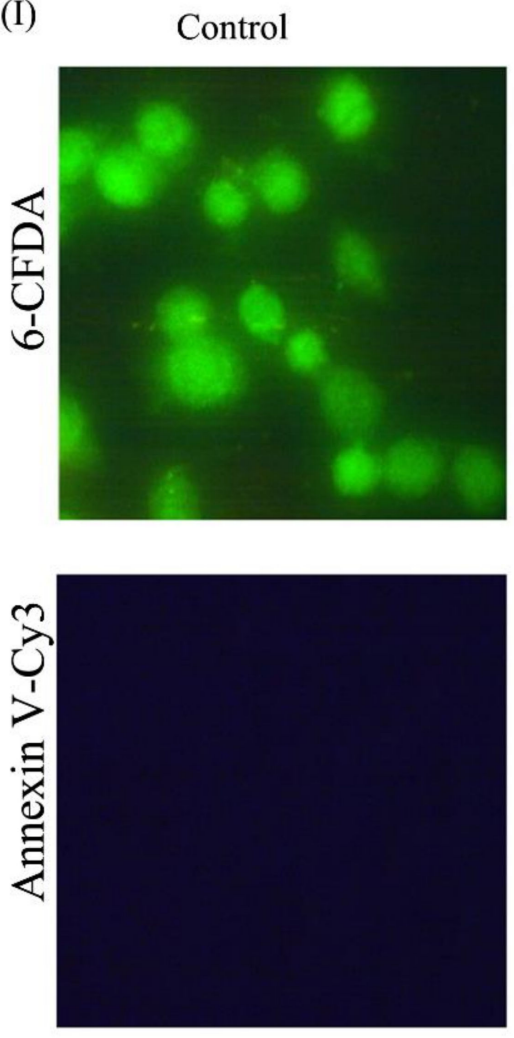

L-HAgNPs
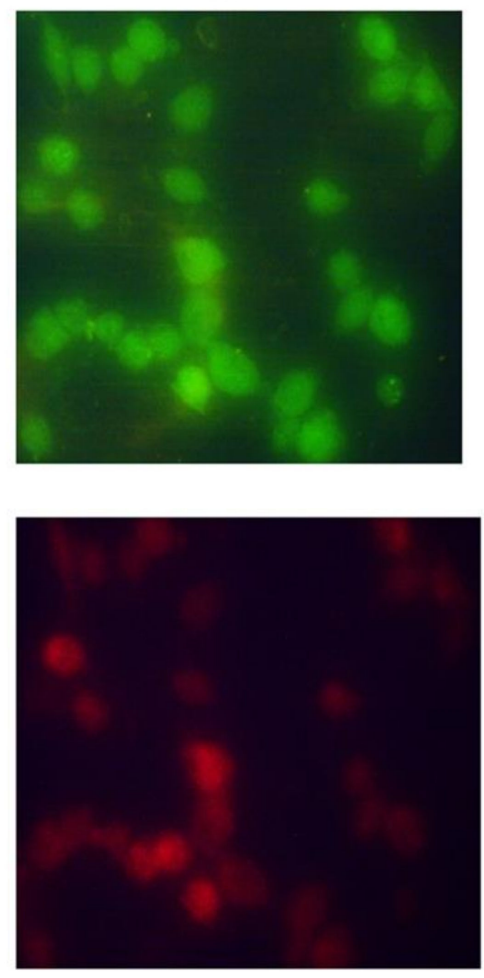

Cisplatin
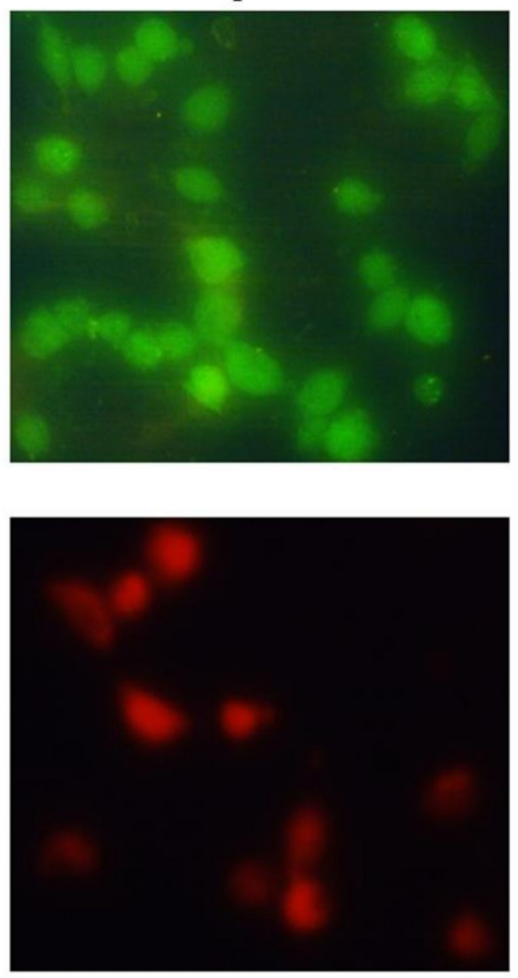

(II)

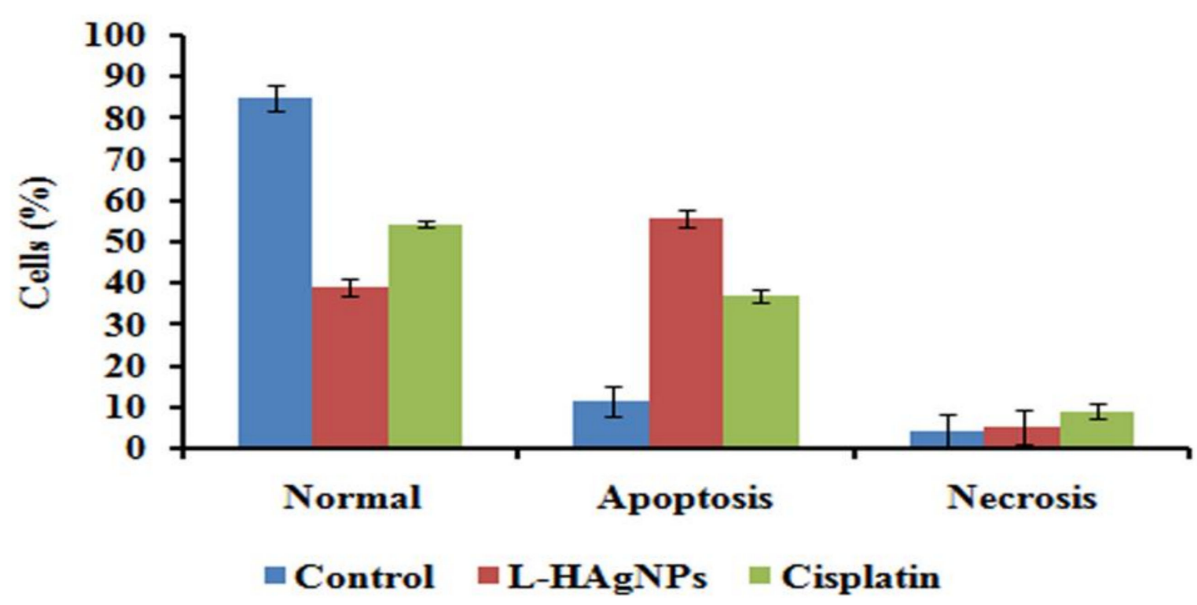

Figure 8. Assessment of L-HAgNPs induced apoptosis in cervical carcinoma cells (SiHa) by annexin-Cy3 (red) and 6CFDA (green) dual staining (I) Fluorescence microscopic image representing apoptotic (green) and healthy cells (red); (II) percentage of apoptotic cells.

\section{Discussion}

Traditional cancer therapeutics involves combinatorial therapy of chemo/Radio/surgery, which has certain limitations such as poor bioavailability, severe side effects due to nonspecific drug delivery, multidrug resistance, and toxicity [26]. Advancement of nanotherapeutics in cancer therapy helped in overcoming limitations such as lack of solubility, specificity, and multidrug resistance. Among the noble metal nanoparticles, AgNPs have been extensively studied for its antitumor potential against various cancer cell lines. Tunable size, plasmonic nature, specificity, and eco-friendly nature of AgNPs makes it a promising theranostic agent for cancer therapy [27-29]. Despite the existence of several lines of evidence on anticancer potential of AgNPs, reports on anticancer potential of Lhistidine-capped 
AgNPs are deficient; hence, this study focused on synthesizing L-histidine-capped AgNPs for cervical cancer therapy.

Fabrication of L-HAgNPs was identified by the color transition from colorless to brown color and further confirmed by the UV-Visible absorption spectrum between 400 and $420 \mathrm{~nm}$, as previously reported by Xu et al. (2020) [30]. Particle size analysis revealed that increased ratio of precursor $\mathrm{AgNO} 3$ and L-histidine decreased the size of synthesized nanoparticles, with the least particle size of $47.43 \pm 19.83 \mathrm{~nm}$ for the precursor ratio $\mathrm{AgNO}_{3}$ : L-histidine (1:2.5). Polydispersity index was observed to be $0.5 \pm 0.2$, indicating uniform dispersion of nanoparticles, as reported by Danaei et al. (2018) [31]. As the particle size of the fabricated nanoparticle is less than $100 \mathrm{~nm}$, these nanoparticles can efficiently be internalized into the cells in accordance to the report of Foroozandeh and Aziz (2018) [32]. Zeta potential value of L-HAgNPs synthesized was observed to be $-20.5 \pm 0.95 \mathrm{mV}$. Negative charge of L-HAgNPs may be derived from COO- group of histidine, and the strong electronegative charge prevents agglomeration of nanoparticles due to electrostatic force of repulsion. The negative zeta potential of L-HAgNPs also promotes the interaction with positively charged site, i.e., transmembrane protein of cell membrane through electrostatic force of attraction, leading to localized neutralization, which favors endocytosis-mediated cellular uptake [33]. XRD analysis of L-HAgNPs revealed face centered cubic crystalline structure, as reported by Iswarya et al. (2017) [17]. FTIR analysis revealed that presence of signals for primary amino group $\left(3328 \mathrm{~cm}^{-1}\right)$ and carboxyl group $\left(1460 \mathrm{~cm}^{-1}\right)$, which is analogous to aminocarboxylates and carboxyl groups present in L-histidine, as reported by Iswarya et al. (2017) [17]. In this study, signals for CH-COO- (1410-1430 $\left.\mathrm{cm}^{-1}\right)$ was not detected, indicating the fact that AgNPs colloids are covered fully by imdiazole ring of L-histidine while carboxyl group is exposed outwards with no contact with AgNPs as per the report Liu et al. (2010) [34]. The morphology of LHAgNPs was probed using SEM, which showed the presence of clusters of needle-shaped structure clearly visible at $200 \mathrm{~nm}$ magnification. Negative charge of L-HAgNPs facilitates the absorption of AgNPs on the 3-Aminopropyl)triethoxysilane (APTES) modified surface via electrostatic interaction for AFM observation. AFM results showed the presence of uniform distribution spherical-shaped structure with average height of $12 \pm 4 \mathrm{~nm}$, which is in accordance to the results of TEM imaging [14].

Anticancer potential of L-HAgNPs against cervical cancer was assessed using SiHa cells the most widely used model system. MTT assay exhibited an enhanced dosedependent reduction in proliferation rate when compared with platinum-based drug cisplatin. In addition, morphological analysis of L-HAgNP-treated groups exhibited a reduction in cell density, adhesion capacity, loss of typical cell shape with shrunken morphology the apoptotic features, suggesting the fact that cytotoxic effect of AgNPs might be due to antineoplastic nature as observed in previous reports $[18,19]$. Most chemotherapeutic drugs act by elevating intracellular ROS levels disproportionally, leading to mitochondrial dysfunction, thereby activating intrinsic apoptotic pathways. Therefore, the assessment of intracellular ROS level and mitochondrial membrane potential acts as an indicator of healthy cells [34]. In this study, the intense green fluorescent intensity in the L-HAgNPtreated group depicts an increase in the intracellular ROS level, the key factor leading to mitochondrial dysfunction ultimately activating apoptotic cascade $[35,36]$. To evaluate the mitochondrial damage, MMP was assessed using JC-1 staining. Vehicle control cells showed enhanced red fluorescence due to the formation of J-aggregates, while L-HAgNPtreated cells exhibited enhanced green fluorescence due to loss of electrochemical potential, which might be due to elevated ROS level, leading to alteration in the mitochondrial membrane permeability as observed in the reports of Yuan et al. (2018) [19]. Recent studies reported that nanoparticle-treated cancer cells exhibited enhanced ROS bursts, which led to oxidative modification of biomolecules such as protein oxidation, DNA fragmentation, and lipid peroxidation, leading to cell death [37]. To verify whether apoptosis is caused due to ROS-induced DNA damage, induced by elevated ROS levels, a comet assay was carried out, which is a widely used method to assess single-strand and double-strand breaks in 
DNA [38]. Results of this study revealed that L-HAgNP-treated cells showed a significant increase in the olive tail moment, tail length, and around $90 \%$ of DNA in the tail when compared with vehicle control, confirming the fact that L-HAgNPs induced significant DNA damage, which acts as one of the key factors for apoptosis. To elucidate the mechanism of cell death, $\mathrm{AO} / \mathrm{EtBr}$ dual staining was carried out, and the results showed the presence of both green and orange fluorescing cells in the L-HAgNP-treated group, depicting both apoptosis- and necrosis-mediated cell death. To detect whether the mechanism of cell death is due to DNA fragmentation, Hoechst 33,528 staining was carried out, which showed the presence of intense blue fluorescent cells with condensed and fragmented nuclei in L-HAgNP-treated cells, coinciding with previous reports on AgNP-treated cervical cancer cells [39]. Annexin V/6CFDA dual staining widely used to segregate viable cells from nonviable cells substantiated the fact that L-HAgNPs induced apoptosis-mediated cell death rather than necrosis. Collectively, the findings of this study reveal that the fabricated L-HAgNPs induce ROS-mediated mitochondrial membrane alteration, thereby activation intrinsic apoptotic pathway leading to cell death, concluding that the L-HAgNPs can effectively mitigate cervical carcinoma.

\section{Conclusions}

This study focused on the synthesis of water-dispersible, ecofriendly L-histidine functionalized AgNPs by a single-step one-pot approach. Fabricated L-HAgNPs in different ratios of precursors exhibited characteristic SPR peaks within a wavelength range of 400-450 nm, corresponding to AgNPs. FT-IR spectrum revealed that L-histidine acts as a reducing and capping agent for L-HAgNPs. SEM topographical images of L-HAgNPs revealed crystalline needle-shaped structure, while DLS revealed the size less than $50 \mathrm{~nm}$ suitable for cellular internalization. The anticancer potential of L-HAgNPs revealed the antineoplastic effect in a concentration-dependent manner. Elucidation of the anticancer mechanism illustrated loss of MMP due to increased ROS level, thereby activating apoptotic pathways and inducing DNA damage, ultimately leading to cell death. Overall, the results reveal that L-HAgNPs is a biocompatible potent candidate for cancer therapy.

Author Contributions: In vitro anticancer screening, R.M.A.; synthesis and characterization of LHAgNPs, C.M., K.T.S. and A.P.A.; writing-original draft preparation, revision, and statistical analysis, R.M.A., C.M. and N.S.; writing-review and editing, D.M.; supervision, G.A., M.S., P.P. and B.G. All authors have read and agreed to the published version of the manuscript.

Funding: This research received no external funding.

Data Availability Statement: Not applicable.

Acknowledgments: R.M.A. thanks Science and Engineering Research Board and Indian Council of Medical Research, New Delhi, India, for providing financial support through SERB - Overseas Visiting Doctoral Fellowship (ODF/2018/001044) and Senior Research Fellow (No. 2017-2853/SCRTBMS). N.S. thanks the University Grants Commission, New Delhi, India, for the financial support through the UGC-Start-Up Grant (Ref. No. F. 30-381/2017 (BSR), dated 6 July 2017) and RUSA-Phase 2.0 grant (No. F. 24-51/2014-U, Policy (TNMulti-Gen), Dept. of Edn. Govt. of India, dated 9 October 2018). D.M. thanks to European Union's Horizon 2020 research and innovation program under grant agreement No 739593. HCEMM supported by EU Program: H2020-EU.4.a. This work was also partly funded by a grant from the Hungarian National Research, Development and Innovation Office (Thematic Excellence Program, TKP-BIOImaging, financed under the 2020-4.1.1-TKP2020 funding scheme). B.G. and P.P. thank Data Science and AI Research (DSAIR) Centre of NTU (Project Number ADH-11/2017-DSAIR), Imaging Probe Development Platform (IPDP), and the support from the Cognitive NeuroImaging Centre (CONIC) at NTU. G.A. acknowledges University Grants Commission, New Delhi, India, for the award of UGC-BSR Faculty Fellow (No. F.18-1/2011(BSR) dt. 4 January 2017). P.P. and B.G. acknowledge the support from Lee Kong Chian School of Medicine and Nanyang Technological University, Singapore.

Conflicts of Interest: The authors declare no conflict of interest. 


\section{References}

1. Ali, S.; Chen, X.; Shi, W.; Huang, G.; Yuan, L.M.; Meng, L.; Chen, S.; Zhonghao, X.; Chen, X. Recent Advances in Silver and Gold Nanoparticles-Based Colorimetric Sensors for Heavy Metal Ions Detection: A Review. Crit. Rev. Anal. Chem. 2021, 1-33.

2. Hai, X.; Zhu, X.; Yu, K.; Yue, S.; Song, W.; Bi, S. Dual-mode glucose nanosensor as an activatable theranostic platform for cancer cell recognition and cascades-enhanced synergetic therapy. Biosens. Bioelectron. 2021, 192, 113544. [CrossRef]

3. Hai, X.; Li, Y.; Yu, K.; Yue, S.; Li, Y.; Song, W.; Bi, S.; Zhang, X. Synergistic in-situ growth of silver nanoparticles with nanozyme activity for dual-mode biosensing and cancer theranostics. Chin. Chem. Lett. 2021, 32, 1215-1219. [CrossRef]

4. Yaqoob, A.A.; Ahmad, H.; Parveen, T.; Ahmad, A.; Oves, M.; Ismail, I.M.; Qari, H.A.; Umar, K.; Mohamad Ibrahim, M.N. Recent advances in metal decorated nanomaterials and their various biological applications: A review. Front. Chem. 2020, 8, 341. [CrossRef]

5. $\quad$ Badawy, A.M.E.; Luxton, T.P.; Silva, R.G.; Scheckel, K.G.; Suidan, M.T.; Tolaymat, T.M. Impact of environmental conditions (pH, ionic strength, and electrolyte type) on the surface charge and aggregation of silver nanoparticles suspensions. Environ. Sci. Technol. 2010, 44, 1260-1266. [CrossRef]

6. Jun, B.H.; Noh, M.S.; Kim, J.; Kim, G.; Kang, H.; Kim, M.S.; Seo, Y.T.; Baek, J.; Kim, J.H.; Park, J.; et al. Multifunctional silver-embedded magnetic nanoparticles as SERS nanoprobes and their applications. Small 2010, 6, 119-125. [CrossRef]

7. Qayyum, S.; Oves, M.; Khan, A.U. Obliteration of bacterial growth and biofilm through ROS generation by facilely synthesized green silver nanoparticles. PLoS ONE 2017, 12, e0181363. [CrossRef]

8. Anjugam, M.; Vaseeharan, B.; Iswarya, A.; Divya, M.; Prabhu, N.M.; Sankaranarayanan, K. Biological synthesis of silver nanoparticles using $\beta-1,3$ glucan binding protein and their antibacterial, antibiofilm and cytotoxic potential. Microb. Pathog. 2018, 115, 31-40. [CrossRef] [PubMed]

9. Tan, P.; Li, H.; Wang, J.; Gopinath, S.C. Silver nanoparticle in biosensor and bioimaging: Clinical perspectives. Biotechnol. Appl. Biochem. 2020, 1-7. [CrossRef] [PubMed]

10. Iravani, S.; Korbekandi, H.; Mirmohammadi, S.V.; Zolfaghari, B. Synthesis of silver nanoparticles: Chemical, physical and biological methods. Res. Pharm. Sci. 2014, 9, 385-406.

11. Rauwel, P.; Rauwel, E.; Ferdov, S.; Singh, M.P. Silver Nanoparticles: Synthesis, Properties, and Applications. Adv. Mater. Sci. Eng. 2015, 2015, 624394. [CrossRef]

12. Kulandaisamy, A.J.; Rayappan, J.B.B. Significance of Nanoparticles and the Role of Amino Acids in Structuring Them-A Review. J. Nanosci. Nanotechnol. 2018, 18, 5222-5233. [CrossRef]

13. Shankar, S.; Rhim, J.W. Amino acid mediated synthesis of silver nanoparticles and preparation of antimicrobial agar/silver nanoparticles composite films. Carbohydr. Polym. 2015, 130, 353-363. [CrossRef] [PubMed]

14. Liu, Z.; Zu, Y.; Fu, Y.; Meng, R.; Guo, S.; Xing, Z.; Tan, S. Hydrothermal synthesis of histidine-functionalized single-crystalline gold nanoparticles and their pH-dependent UV absorption characteristic. Colloids Surf. B Biointerfaces 2010, 76, 311-316. [CrossRef] [PubMed]

15. Zakaria, H.M.; Shah, A.; Konieczny, M.; Hoffmann, J.A.; Nijdam, A.J.; Reeves, M.E. Small molecule-and amino acid-induced aggregation of gold nanoparticles. ACS Langmuir 2013, 29, 7661-7673. [CrossRef] [PubMed]

16. Peralta-Zaragoza, O.; Bermúdez-Morales, V.H.; Pérez-Plasencia, C.; Salazar-León, J.; Gómez-Cerón, C.; Madrid-Marina, V. Targeted treatments for cervical cancer: A review. OncoTargets Ther. 2012, 5, 315-328. [CrossRef] [PubMed]

17. Daduang, J.; Palasap, A.; Daduang, S.; Boonsiri, P.; Suwannalert, P.; Limpaiboon, T. Gallic Acid Enhancement of Gold Nanoparticle Anticancer Activity in Cervical Cancer Cells. Asian Pac. J. Cancer Prev. 2015, 16, 169-174. [CrossRef] [PubMed]

18. Al-Sheddi, E.S.; Farshori, N.N.; Al-Oqail, M.M.; Al-Massarani, S.M.; Saquib, Q.; Wahab, R.; Musarrat, J.; Al-Khedhairy, A.A.; Siddiqui, M.A. Anticancer potential of green synthesized silver nanoparticles using extract of Nepeta deflersiana against human cervical cancer cells (HeLA). Bioinorg. Chem. Appl. 2018, 2018, 9390784. [CrossRef]

19. Yuan, Y.G.; Zhang, S.; Hwang, J.Y.; Kong, I.K. Silver Nanoparticles Potentiates Cytotoxicity and Apoptotic Potential of Camptothecin in Human Cervical Cancer Cells. Oxid. Med. Cell. Longev. 2018, 2018, 6121328. [CrossRef] [PubMed]

20. Iswarya, C.N.; Daniel, S.K.; Sivakumar, M. 2017. Studies on L-histidine capped Ag and Au nanoparticles for dopamine detection. Mater. Sci. Eng. C 2017, 75, 393-401. [CrossRef] [PubMed]

21. Mosmann, T. Rapid colorimetric assay for cellular growth and survival: Application to proliferation and cytotoxicity assays. $J$. Immunol. Methods 1983, 65, 55-63. [CrossRef]

22. Roesslein, M.; Hirsch, C.; Kaiser, J.P.; Krug, H.F.; Wick, P. Comparability of in Vitro Tests for Bioactive Nanoparticles: A Common Assay to Detect Reactive Oxygen Species as an Example. Int. J. Mol. Sci. 2013, 14, 24320-24337. [CrossRef] [PubMed]

23. Spector, D.L.; Goldman, R.D.; Leinwand, L.A. Cells: A Laboratory Manual. Volume 1: Culture and Biochemical Analysis of Cells. Biol. Plant. 1999, 42, 440.

24. Kasibhatla, S.; Amarante-Mendes, G.P.; Finucane, D.; Brunner, T.; Bossy-Wetzel, E.; Green, D.R. Staining of Suspension Cells with Hoechst 33258 to Detect Apoptosis. Cell: A Laboratory Manual Culture and Biochemical Analysis of Cells; CSHL Press: Long Island, NY, USA, 1998; p. 5. [CrossRef]

25. Tice, R.R.; Agurell, E.; Anderson, D.; Burlinson, B.; Hartmann, A.; Kobayashi, H.; Miyamae, Y.; Rojas, E.; Ryu, J.C.; Sasaki, Y.F. Single cell gel/comet assay: Guidelines for in vitro and in vivo genetic toxicology testing. Environ. Mol. Mutagen. 2000, 35, 206-221. [CrossRef] 
26. Hidambaram, M.; Manavalan, R.; Kathiresan, K. Nanotherapeutics to Overcome Conventional Cancer Chemotherapy Limitations. J. Pharm. Pharmaceut. Sci. 2011, 14, 67-77.

27. George, B.P.A.; Kumar, N.; Abrahamse, H.; Ray, S.S. Apoptotic efficacy of multifaceted biosynthesized silver nanoparticles on human adenocarcinoma cells. Sci. Rep. 2018, 8, 14368. [CrossRef]

28. Ratan, Z.A.; Haidere, M.F.; Nurunnabi, M.; Shahriar, S.M.; Ahammad, A.J.; Shim, Y.Y.; Reaney, M.J.; Cho, J.Y. Green Chemistry Synthesis of Silver Nanoparticles and Their Potential Anticancer Effects. Cancers 2020, 12, 855. [CrossRef]

29. Huy, T.Q.; Huyen, P.T.M.; Le, A.T.; Tonezzer, M. Recent Advances of Silver Nanoparticles in Cancer Diagnosis and Treatment. Anticancer Agents Med. Chem. 2020, 20, 1276-1287. [CrossRef]

30. Xu, L.; Wang, Y.Y.; Huang, J.; Chen, C.Y.; Wang, Z.X.; Xie, H. Silver nanoparticles: Synthesis, medical applications and biosafety. Theranostics 2020, 10, 8996-9031. [CrossRef]

31. Danaei, M.; Dehghankhold, M.; Ataei, S.; Hasanzadeh Davarani, F.; Javanmard, R.; Dokhani, A.; Khorasani, S.; Mozafari, M.R. Impact of Particle Size and Polydispersity Index on the Clinical Applications of Lipidic Nanocarrier Systems. Pharmaceutics 2018, 10, 57. [CrossRef]

32. Foroozandeh, P.; Aziz, A.A. Insight into Cellular Uptake and Intracellular Trafficking of Nanoparticles. Nanoscale Res. Lett. 2018, 13, 339. [CrossRef] [PubMed]

33. Honary, S.; Zahir, F. Effect of zeta potential on the properties of nano-drug delivery systems-a review (Part 1). Trop. J. Pharm. Res. 2013, 12, 255-264.

34. Tang, Z.; Liu, Y.; He, M.; Bu, W. Chemodynamic therapy: Tumour microenvironment-mediated fenton and fenton-like reactions. Angew. Chem. Int. Ed. 2019, 131, 958-968. [CrossRef]

35. Simon, H.U.; Haj-Yehia, A.; Levi-Schaffer, F. Role of reactive oxygen species (ROS) in apoptosis induction. Apoptosis 2000, 5, 415-418. [CrossRef]

36. Perillo, B.; Di Donato, M.; Pezone, A.; Di Zazzo, E.; Giovannelli, P.; Galasso, G.; Castoria, G. Migliaccio, A. ROS in cancer therapy: The bright side of the moon. Exp. Mol. Med. 2020, 52, 192-203. [CrossRef]

37. Zhang, C.; Wang, X.; Du, J.; Gu, Z.; Zhao, Y. Reactive Oxygen Species-Regulating Strategies Based on Nanomaterials for Disease Treatment. Adv. Sci. 2021, 8, 2002797. [CrossRef] [PubMed]

38. Catalán, J.; Suhonen, S.; Huk, A.; Dusinska, M. Analysis of nanoparticle-induced DNA damage by the comet assay. In Genotoxicity and DNA Repair; Humana Press: New York, NY, USA, 2014; pp. 241-268.

39. Vasanth, K.; Ilango, K.; MohanKumar, R.; Agrawal, A.; Dubey, G.P. Anticancer activity of Moringa oleifera mediated silver nanoparticles on human cervical carcinoma cells by apoptosis induction. Colloids Surf. B Biointerfaces 2014, 117, 354-359. [CrossRef] [PubMed] 